\title{
Evaluation of Fish Pond Effluent as an Organic Fertilizer in Comparison with Poultry and Pig Manures in the Cultivation of Pineapple (Ananas comosus)
}

\author{
${ }^{1}$ Dominic J. Udoh and ${ }^{2}$ Otobong B. Iren \\ ${ }^{I}$ Department of Soil Science, Akwa Ibom State University, Obio Akpa, Akwa Ibom State, Nigeria \\ ${ }^{2}$ Department of Soil Science, University of Calabar, Calabar,Cross River State, Nigeria
}

\begin{abstract}
Fish pond effluent (PW) was evaluated with poultry manure (PM), pig manure $(P G)$ and the inorganic fertilizer (NPK15:15:15) for effectiveness as an organic fertilizer. Experimental plots were laid out as a split plot in RCBD with four main treatments consisting of $P W, P M, P G$ and NPK, and five sub-treatments consisting of nitrogen $(N)$ rates of $0,150,300,450$ and $600 \mathrm{kgha}^{-1}$. The results showed that soil pH increased slightly beyond pre-treatment level at the first rates of manures and NPK but did not increase further as rates increased. Plots treated with $P W$ were significantly $(P<0.05)$ higher in soil $O M, N, P, C a$ and bulk density, followed by $P G$ treated plots. Growth improvement was highest in the order $P M>N P K>P W>P G$, and fruit yield in the order $P M>N P K=P G>P W$. The growth of pineapple increased with incremental rates of manures from about 3 tha ${ }^{-1}$ in the control to about 9 tha $^{-1}$ at the manure rates that supplied $N$ at $300-450 \mathrm{~kg}$ $\mathrm{Nha}^{-1}(P<0.05)$, before dropping at $600 \mathrm{~kg} \mathrm{Nha}{ }^{-1}$.
\end{abstract}

Keywords: fish pond effluent, growth parameters, manure application rates, pineapple, soil chemical properties

\section{Introduction}

The fertility status of the sandy ultisols common in the humid, rain-forest zone of south eastern Nigeria, is generally low, and so crop yields are poorer than obtained in most other regions of the country, except where fertility management is well organised. The common technologies taught to farmers for the maintenance of soil fertility have been in the use of inorganic fertilizers, improved crop species/varieties, crop rotation, and the role of agro-chemicals. These approaches are no more adequate, the reasons including excessive degradations of soils by a high rainfall regime - which inorganic fertilizers cannot correct; high cost of fertilizers and need for repetitive applications, which many farmers can no more afford, and the desire by many people to eat organically produced foodstuffs [1].

The great dependence on inorganic fertilizers had of course been fostered by the massive increases achieved in crop production through their use. The dependence was bolstered by the fact that inorganic fertilizers were easy to handle, and contained high concentrations of nutrients that remained relatively stable over time, unlike manure fertilizers which, in being bio-active, changed quality over time, especially under moist conditions [2]. Nevertheless, by reasons of a better appreciation of the effects of manures on soil properties, plus changing attitudes against agro-chemicals use in foodstuff production, pressure had mounted for the development of fertility management technologies that utilized organic fertilizers or combinations of organic and inorganic fertilizers [3]. Such manures from poultry, pigs, rabbits, which contained relatively high amounts of N, P and K, drew particular attention. Researchers [4] have reported on the positive impacts of organic manures on the sustained production of waterleaf. Also [5] reported on the positive impacts of organic fertilizers on the root growth and yield of maize while [6] reported on the highly positive impacts of integrated applications of poultry manure and mineral fertilizers on nutrient uptake and yield of maize. Several researchers have reported that soils amended with animal manures significantly improved soil productivity and the yield of crops ([7, 8, 9]. It has also been pointed out by [6] that organic fertilizers improve soil CEC, nutrient assay, soil structure, base saturation and bulk density.

As it usually happens with chemical fertilizers, large and prolonged applications of manures can also cause environmental hazards, such as stream and river pollution, soil acidification and soil salinity [10]. Other challenges of using organic manures include bulkiness, low nutrient analyses, and difficulty in quality standardization and cumbersomeness in application. These can be minimized, however, through a processing of the manures [11], sourcing of manures that are available at close proximity, and selection of manures with higher nutrient analyses that can be upgraded with additions of chemical fertilizers.

The development of integrated farming has afforded better opportunity for the testing of different manures, singly or in combination. It is equally necessary to verify the proper rates of the manure fertilizers to apply under different soil and climatic conditions. It has been shown [12] that pond waste water supported the 
growth of garden eggs at equal level as did pig manure and gave higher yields than poultry litter and NPK15:15:15 when applied at rates that supplied $\mathrm{N}$ at the rate of $150-300 \mathrm{kgha}^{-1}$. Food and Agriculture Organization of the United Nation (FAO) [13] had also reported that combinations of fish farming and crop cultivation was well developed in China where the nutrient-rich residues that settled in fish ponds, while indicating a deteriorated state of water on the one hand, rather proved to be a high-quality manure when applied to crops, on the other. The crops, in turn, were utilized in the preparation of fish feeds; and so pond silt constituted the link in fish and crop integration.

The purpose of this study was to evaluate the suitability of fish pond effluent (pond waste water) as a fertilizer in the cultivation of a longer season crop like pineapples and to also assess its effects on soil properties in comparison with poultry litter, pig manure and NPK15:15:15.

\subsection{Site Conditions}

\section{Materials and methods}

The experiment was conducted at Domita Farms located on Ring Road 4, off Nwaniba Rd., Uyo, Akwa Ibom State. The farm operates an integrated programme of crop, livestock and aquaculture production, as well as agro-processing. The 'apparent' waste products of one project are applied as inputs to others. The soils of the area are coastal plain, acid sand ultisols (Acrisols and Ferralsols in the new WRB soil classification system), which require good management to be productive. Uyo lies between latitudes $7^{\circ} 47^{\prime}$ and $8^{\circ} 3^{\prime} \mathrm{N}$, and longitudes $4^{\circ} 52^{\prime}$ and $5^{\circ} 7^{\prime}$ E.

The farm is located on a nearly flat upland plain formerly covered by secondary forests of wild palm trees and hard woods. The climate is sub-equatorial with an annual rainfall that ranges from $2800-3600 \mathrm{~mm}$ with relative humidity of $75-95 \%$ and mean minimum/maximum temperature of $24{ }^{\circ} \mathrm{C} / 30{ }^{\circ} \mathrm{C}$ (University of Uyo, Agro Meteorological Unit). Highest temperatures occur February to April, and rainfalls are heaviest July September. The geological materials of the area belong to the recent, tertiary and cretaceous periods. The recent types are alluvial deposits, while the tertiary types comprise of coastal plain sands, shale, sandstone and beach ridge sands. The soils developed from these parent materials are dominated by low activity clays such as kaolinite and the hydrous oxides of iron (Fe) and aluminium ( $\mathrm{Al})$.

\subsection{Materials used}

A field experiment was conducted in 2014 cropping season to compare the effectiveness of fish pond effluent (PW), poultry manure (PM), pig manure (PG) and NPK 15:15:15 (NPK) in the cultivation of pineapple. The manures used in the experiments were obtained from Domita Farms while NPK was bought from the market. Pineapple suckers were also obtained from Domita Farms. Samples of the manures were sent to the laboratory for analyses. Fish pond effluent was dried and calibrated to establish the volumes that would supply equivalent amounts of $\mathrm{N}$ nutrient to be applied ( $\mathrm{N}$ as the reference factor) in comparison with the other manures and NPK.

\subsection{Field Experiments}

The field site, a 2 year fallow land under wild legumes, guinea grass and other assorted weeds was cleared in October 2014, treated with herbicides to destroy stubborn weeds and tilled to suit the cultivation of pineapple. Experimental plots were laid out as a split plot in randomized complete block design (RCBD) with four main treatments (PW, PM, PG, NPK) and five sub-treatments ( $\mathrm{N}$ rates; 0, 150, 300, 450 and $600 \mathrm{kgha}^{-1}$ ), all in 3 replicates (total of 60 plots, each measuring $2 \mathrm{~m} \mathrm{x} 1.5 \mathrm{~m}\left(3.0 \mathrm{~m}^{2}\right.$ ), with a space of $0.5 \mathrm{~m}$ separating the plots and $1.2 \mathrm{~m}$ separating the blocks). The PM and PG manures were composted before use. The 3 solid materials (PM, PG and NPK) were applied by spreading appropriate rates on the plots and incorporating them into the soil, while PW was applied by pouring aliquot quantities per treatment rate on each plot. The manures and NPK were measured to supply nitrogen at 0, 150, 300, 450 and $600 \mathrm{kgha}^{-1}$ (TABLE 1). After application, the plots were lightly mulched and the manures allowed equilibration for 3 days before pineapple suckers were planted. Weeding was done as necessary while observations were taken on the growth rate, fruit initiation and yield of crop. Composite samples of the soil were taken before and after experiment for routine analysis.

\subsection{Laboratory Methods}

All the soil samples were air dried and passed through a $2 \mathrm{~mm}$ sieve before analyses. The manure and composite soil samples were analysed using standard procedures as outlined by [14]. Particle size distribution was determined by the hydrometer method; soil $\mathrm{pH}$ was determined with glass electrode $\mathrm{pH}$ meter in 1:2.5 soil/water; organic matter (OM) was by the wet oxidation method, and electrical conductivity was measured in a soil/water slurry with the conductivity bridge. Calcium $(\mathrm{Ca})$, magnesium $(\mathrm{Mg})$ and potassium $(\mathrm{K})$ were extracted with $1 \mathrm{M} \mathrm{NH}_{4} \mathrm{OAc}$ and $\mathrm{Ca}$ and $\mathrm{Mg}$ determined by EDTA titration, and $\mathrm{K}$ by flame photometer. Total nitrogen $(\mathrm{N})$ was determined by Micro-Kjeldhal digestion method while Available phosphorus (P) was 
extracted by the Bray 1 extraction method, and the content of $\mathrm{P}$ was determined colorimetrically using a Technico AAII auto analyser (Technico, Oakland, Calif). Effective cation exchange capacity (ECEC) was determined by the IITA summation method, where ECEC = TEB + TEA. TEB is total exchangeable bases and TEA, total exchangeable acidity (determined with $\mathrm{KCl}$, using displacement method). Percent base saturation was calculated as:

$$
\% \mathrm{BS}=\frac{\mathrm{TEB}}{\mathrm{CEC}} \times \frac{100 .}{1}
$$

The field and laboratory data were analyzed according to the procedures outlined by [15] using Genstat package and significant means were compared using Fisher's least significant difference (FLSD) at $5 \%$ level of probability.

TABLE 1: Quantities of manures and NPK applied

\begin{tabular}{|c|c|c|l|c|}
\hline \multirow{2}{*}{$\begin{array}{l}\text { Equivalent } \\
\text { N-Rates }(\mathrm{kg} / \mathrm{ha})\end{array}$} & \multicolumn{5}{|l|}{ Fertilizer Type and N content } \\
\cline { 2 - 5 } & PM (N=1.5\%) & PG $(\mathrm{N}=1.6 \%)$ & PW $(\mathrm{N}=1.8 \%)$ & NPK $(\mathrm{N}=15.0 \%)$ \\
\cline { 2 - 5 } & $($ Tonnes/ha) & $($ Tonnes/ha) & $($ Tonnes/ha) & (Tonnes/ha) \\
\hline 0 (Control) & 0 & 0 & 0 & 0 \\
\hline 150 & 10.0 & 9.4 & 8.3 & 1.0 \\
\hline 300 & 20.0 & 18.8 & 16.7 & 2.0 \\
\hline 450 & 30.0 & 28.1 & 25.0 & 3.0 \\
\hline 600 & 40.0 & 37.5 & 33.3 & 4.0 \\
\hline
\end{tabular}

The quantity of manure or fertilizer to apply per $\mathrm{N}$ rate was calculated on the basis of the $\mathrm{N}$ content of the material

\section{Results and discussion \\ 3.1 Chemical composition of the organic fertilizers and properties of the soil used for the experiment}

The results of the chemical analyses of the three manures used are as given in TABLE 2. There was similarity in reaction when $\mathrm{pH}$ was tested in water slurry. Although microbial decomposition of organic matter generates some acidity, the alkaline levels of these manures indicate them as not being direct soil acidifiers. Pond effluence is particularly low in $\mathrm{P}$ and $\mathrm{Mg}$. Similar trend has also been observed by [16] with pond waste water in Egypt while [17, 18] also observed that manures were very low in the primary nutrients $\mathrm{N}, \mathrm{P}$ and $\mathrm{K}$ compared with inorganic fertilizers. Pond effluent (PW) showed similar levels of pH, EC and OM as poultry manure (PM) but differed greatly in its contents of $\mathrm{P}$ and $\mathrm{Mg}$ which were very low. Pig manure (PG) was similar to PM in contents of the macro-nutrients. Fish feeds are much more processed than either poultry or pig feeds and tend to be more digestible so that the residues are usually relatively poor in the primary and secondary nutrients. TABLE 3 presents data on properties of the soil before experiment. The soil used was loamy sand in texture and strongly acid with a $\mathrm{pH}\left(\mathrm{H}_{2} \mathrm{O}\right)$ value of 5.2. The soil was generally low in total nitrogen $(0.90 \mathrm{~g} / \mathrm{kg})$, exchangeable bases, ECEC $(7.44 \mathrm{cmol} / \mathrm{kg})$ but high in organic matter $(34.0 \mathrm{~g} / \mathrm{kg})$ and base saturation $(72.04 \%)$ and moderate in available phosphorus $(8.99 \mathrm{mg} / \mathrm{kg})$, when compared to the critical minimum for Nigerian soils [19].

TABLE 2: Chemical Properties of the Manures and Fertilizer Used

\begin{tabular}{|c|c|c|c|c|c|c|c|c|}
\hline Manure & $\mathrm{pH}$ & $\begin{array}{l}\mathrm{EC} \\
\mathrm{dSm}^{-1}\end{array}$ & $\begin{array}{l}\mathrm{OM} \\
\%\end{array}$ & $\begin{array}{c}\text { Total N } \\
\%\end{array}$ & $\begin{array}{l}\mathrm{P} \\
-\end{array}$ & $\mathrm{mg} / \mathrm{kg}$ & $\mathrm{Mg}$ & \\
\hline PW & 8.7 & 1.12 & 47 & 1.8 & 90 & 4000 & 1991 & 44 \\
\hline PM & 8.7 & 1.36 & 53 & 1.5 & 1080 & 3600 & 1884 & 6010 \\
\hline PG & 8.1 & 1.97 & 27 & 1.6 & 1020 & 3200 & 2011 & 4860 \\
\hline \multirow[b]{2}{*}{ NPK: $15^{3}$} & \multirow[b]{2}{*}{ - } & \multirow[b]{2}{*}{ - } & \multirow[b]{2}{*}{ - } & $\ldots \ldots$ & $--\%----$ & \multirow{2}{*}{\multicolumn{2}{|c|}{$\begin{array}{l}--- \\
15\end{array}$}} & \multirow[t]{2}{*}{-} \\
\hline & & & & 15 & & & & \\
\hline
\end{tabular}

$\mathrm{PM}=$ Poultry manure; $\quad \mathrm{PG}=$ Pig manure $; \mathrm{PW}=$ Pond waste water

TABLE 3: Properties of the soil before experiment.

\begin{tabular}{|c|c|}
\hline Parameter & Value \\
\hline Sand (\%) & 85.92 \\
\hline Silt $(\%)$ & 2.44 \\
\hline Clay (\%) & 11.64 \\
\hline Texture & Loamy sand \\
\hline $\mathrm{EC}(\mathrm{dS} / \mathrm{m})$ & 0.02 \\
\hline $\mathrm{BD}\left(\mathrm{Mg} / \mathrm{m}^{3}\right)$ & 1.88 \\
\hline $\mathrm{pH}\left(\mathrm{H}_{2} \mathrm{O}\right)$ & 5.2 \\
\hline Org. matter $(\mathrm{g} / \mathrm{kg})$ & 34.0 \\
\hline Total N $(\mathrm{g} / \mathrm{kg})$ & 0.90 \\
\hline Av. $P(\mathrm{mg} / \mathrm{kg})$ & 8.99 \\
\hline Exchangeable cations $(\mathrm{cmol} / \mathrm{kg})$ & \\
\hline $\mathrm{Ca}^{2+}$ & 3.60 \\
\hline $\mathrm{Mg}^{2+}$ & 1.40 \\
\hline $\mathrm{K}^{+}$ & 0.25 \\
\hline $\mathrm{Na}^{+}$ & 0.11 \\
\hline Exchangeable acidity $(\mathrm{cmol} / \mathrm{kg})$ & 2.08 \\
\hline ECEC & 7.44 \\
\hline B.S (\%) & 72.04 \\
\hline
\end{tabular}

$\mathrm{ECEC}=$ Effective Cation Exchange Capacity, B.S = Base Saturation, EC=Electrical conductivity, BD= Bulk density 
Evaluation of Fish Pond Effluent as an Organic Fertilizer in Comparison with Poultry and Pig ..

TABLE 4: Effects of Pond Effluent, other Manures and NPK fertilizer on Soil Properties

\begin{tabular}{|c|c|c|c|c|c|c|c|c|c|c|c|c|c|c|c|c|c|c|c|c|}
\hline \multirow{2}{*}{$\begin{array}{l}\text { Soil } \\
\text { Properties }\end{array}$} & \multicolumn{5}{|c|}{ PW } & \multicolumn{5}{|c|}{ PM } & \multicolumn{5}{|c|}{ PG } & \multicolumn{5}{|c|}{ NPK } \\
\hline & 1 & 2 & 3 & 4 & 5 & 1 & 2 & 3 & 4 & 5 & 1 & 2 & 3 & 4 & 5 & 1 & 2 & 3 & 4 & 5 \\
\hline $\mathrm{pH}\left(\mathrm{H}_{2} \mathrm{O}\right)$ & 6.05 & 5.85 & 5.79 & 5.88 & 5.84 & 5.61 & 5.70 & 5.70 & 5.67 & 5.70 & 5.94 & 5.75 & 5.70 & 5.67 & 5.84 & 5.57 & 5.51 & 5.34 & 5.23 & 5.41 \\
\hline $\mathrm{OM}(\%)$ & 3.80 & 4.50 & 4.30 & 5.19 & 4.20 & 2.40 & 2.80 & 2.84 & 2.21 & 2.06 & 3.50 & 3.20 & 5.09 & 3.70 & 4.20 & 2.16 & 2.10 & 2.70 & 2.20 & 2.30 \\
\hline Total N (g/kg) & 0.07 & 0.05 & 0.07 & 0.07 & 0.07 & 0.10 & 0.05 & 0.05 & 0.05 & 0.03 & 0.06 & 0.05 & 0.07 & 0.06 & 0.07 & 0.03 & 0.02 & 0.03 & 0.04 & 0.05 \\
\hline Av. P (mg/kg) & 38.2 & 40.6 & 39.1 & 41.1 & 42.5 & 18.1 & 21.1 & 24.0 & 21.2 & 24.2 & 21.0 & 26.2 & 27.9 & 30.7 & 42.5 & 23.0 & 25.3 & 19.3 & 25.5 & 36.8 \\
\hline $\mathrm{Ca}(\mathrm{cmol} / \mathrm{kg})$ & 4.06 & 6.80 & 4.89 & 5.02 & 5.63 & 3.00 & 2.30 & 5.79 & 2.38 & 3.09 & 4.60 & 4.84 & 4.88 & 4.31 & 5.63 & 2.87 & 2.44 & 3.00 & 2.82 & 2.94 \\
\hline $\mathrm{K}(\mathrm{cmol} / \mathrm{kg})$ & 0.44 & 0.72 & 0.50 & 0.63 & 0.53 & 0.35 & 0.34 & 0.40 & 0.22 & 0.19 & 0.88 & 0.46 & 0.52 & 0.35 & 0.53 & 0.19 & 0.22 & 0.21 & 0.16 & 0.28 \\
\hline $\mathrm{BD}\left(\mathrm{Mg} / \mathrm{m}^{3}\right)$ & 1.48 & 1.43 & 1.50 & 1.44 & 2.04 & 1.82 & 1.81 & 1.80 & 1.60 & 1.44 & 1.40 & \begin{tabular}{|l|}
1.54 \\
\end{tabular} & 1.30 & 1.45 & 2.04 & 1.55 & 1.61 & 1.74 & 1.61 & \begin{tabular}{|l|}
1.67 \\
\end{tabular} \\
\hline
\end{tabular}

$\mathrm{PW}=$ Pond waste water; $\mathrm{PM}=$ Poultry manure; $\mathrm{PG}=$ Pig manure; $\mathrm{OM}=$ Organic matter; $\mathrm{BD}=\mathrm{Bulk}$ density $1=0 \mathrm{~kg} \mathrm{~N} / \mathrm{ha}, 2=150 \mathrm{~kg} \mathrm{~N} / \mathrm{ha}, 3=300 \mathrm{~kg} \mathrm{~N} / \mathrm{ha}, 4=450 \mathrm{~kg} \mathrm{~N} / \mathrm{ha}, 5=600 \mathrm{~kg} \mathrm{~N} / \mathrm{ha}$ rate of application

\subsection{Effects of Pond Effluent, other Manures and NPK fertilizer on Soil Properties}

The test results for untreated soil are given on Table $1 \mathrm{~b}$ and the rates of application of manures and NPK (based on N contents) on Table 2. Effect of treatments after 6 months of application (Table 4) showed that soil $\mathrm{pH}$ increased generally above pre-treatment levels for all manures, particularly at the first level above control. Beyond the first level changes were minimal, and this is in line with reports by [20] and [21], that organic matter had a buffering effect on soil $\mathrm{pH}$ change: acidity may increase or decrease according to other related factors, such as rate of cation removal, concentration of associated anions, type of organic material and intensity of microbial decomposition.

Soil organic matter increased as manure rates increased, mostly in plots treated with PW, which also supported higher soil test values for total $\mathrm{N}$, available $\mathrm{P}$, exchangeable $\mathrm{Ca}, \mathrm{Mg}$ and $\mathrm{K}$ than did PM and NPK. The test values for these properties were closer between PG and PW treated plots. From the manure analyses data, total $\mathrm{N}$ was slightly higher in PW than in PG and PM, but that would not explain the higher soil test values of $\mathrm{N}$ since the plots under PW are equally high in $\mathrm{P}$ and $\mathrm{K}$ whereas $\mathrm{PW}$ is very low in total $\mathrm{P}$ and $\mathrm{Mg}$ although high in $\mathrm{K}$. Soil available sources of $\mathrm{P}, \mathrm{K}$ and $\mathrm{Mg}$ would of course be the major influence on their soil test values.

\subsection{Effects of Pond Effluent, other Manures and NPK fertilizer on Fruit Initiation and Yield}

The general blooming time of pineapple differed among treatments (TABLE 5). By mid fruiting season one-third of the crops under PM had bloomed, followed by crops under NPK, and then those under PW while those under PG came into bloom later. A good fertilizer for pineapple should promote early fruiting.

Fruit yield (TABLE 5) was nearly 9 tonnes ha $^{-1}$ under PM, followed by equal yield between PG and NPK at nearly 6 tonnes ha ${ }^{-1}$. Yield, at less than 4 tonnes ha ${ }^{-1}$, was lowest in treatments with PW. This is contrary to what was observed when garden egg was used as a test crop [12] as PW and PG treatments supported significantly $(\mathrm{P}<0.05)$ the highest yields of the crop compared to PM and NPK. Crops with short life cycles like garden egg would benefit more from single application of pond effluent treatment. On account of the longer growth cycle of pineapple crop and also by reason of high loss of nutrients under the very high rainfall regime peculiar to the coastal rainforest zone of south eastern Nigeria, split applications of pond effluent may be necessary. Pineapple is a biennial crop and fertilizers that release nutrients over longer periods support higher yields. Poultry manure contained, overall, the highest total assay of nutrients as well as organic matter, and so had the highest impact. As manifested by the impacts of the manures and NPK on yield parameters the higher test values of soil nutrients under PW would seem to relate more to a low degree of uptake by the crop, which yielded low - at less than one-half the rate under PM - in this experiment. Pond effluent was particularly low in $\mathrm{P}$ and $\mathrm{Mg}$ and as these are important nutrients in root and leaf tissue development, and in chlorophyll formation, manures that are low in them would not support optimal growth and yield.

The largest fruits were obtained on plots treated with PG but these were not significantly different from the fruits obtained from PM plots. Smaller fruits were more common on the NPK and PW plots. Both fruit numbers and size are important, economically.

ANOVA data are given on TABLE 6 to show the relative impact of the different sources of variation in growth response to the treatment factors. Whereas the effects of blocking (experimental design), manure type and rate are highly significant, the effects of interaction are not except in the case of fruit size. The manures are therefore showing similar impact on the growth of the pineapples. Fish pond effluent can rightly be utilized as 
an organic fertilizer in the production of pineapple so long as consideration is given to its relatively lower contents of the primary nutrients. Repeated application, in the course of irrigating the crop would provide for sustainability in the supply of nutrients and lead to better yield than observed in single dose application.

\section{Summary and conclusion}

For the manures tested, the results of this experiment have indicated that amounts that supply $\mathrm{N}$ at 300 - $450 \mathrm{kgha}^{-1}$ will modify soil properties positively and support high yields of pineapple and similar biennial crops. Growth was retarded at higher rate and was thus an unnecessary waste for the sandy ultisol involved in this study. The low impact on yield observed for pond effluent might be related to the effects of a single dose application for a biennial crop. Multiple applications would give better results especially when applied in support of irrigation over the dry season.

An impact ranking of the fertilizers under test gave the yield order: PM $>$ PG $>$ NPK $>$ PW. This indicates that the manures PM and PG were superior to NPK15 $5^{3}$ in supporting the growth and yield of pineapples. From this observation, it is clearly advisable to use manures in the maintenance of soil fertility in ultisols. The optimum rates for pineapple, a biennial crop, were noted to be fertilizer amounts that supplied $\mathrm{N}$ at $300-450 \mathrm{~kg} \mathrm{Nha}^{-1}$. The results of this experiment demonstrated that fish pond effluent could be used as an organic fertilizer once the sample contained nitrogen and other essential nutrients at levels at levels above critical values for the crop of interest. Further studies on the application of pond effluent in split doses would be necessary.

TABLE 5: Effects of Pond Effluent, other Manures and NPK fertilizer on Yield Parameters of Pineapples

\begin{tabular}{|c|c|c|c|c|c|c|c|}
\hline \multirow[t]{2}{*}{ Yield Parameter } & \multirow{2}{*}{$\begin{array}{l}\text { Type of } \\
\text { Fertilizer }\end{array}$} & \multicolumn{6}{|c|}{ Application Rate } \\
\hline & & 0 & 150 & 300 & 450 & 600 & Mean \\
\hline \multirow{5}{*}{$\begin{array}{l}\text { F/Initiation } \\
\text { (midway in the } \\
\text { fruiting season) }\end{array}$} & PW & 2 & 3 & 4 & 4 & 2 & $3.0^{\mathrm{b}}$ \\
\hline & PM & 2 & 4 & 5 & 6 & 3 & $4.0^{\mathrm{a}}$ \\
\hline & PG & 3 & 2 & 3 & 4 & 2 & $2.8^{\mathrm{b}}$ \\
\hline & NPK & 3 & 3 & 4 & 4 & 4 & $3.6^{\mathrm{ab}}$ \\
\hline & Mean & $2.5^{\mathrm{d}}$ & $3.0^{\mathrm{c}}$ & $4.0^{\mathrm{ab}}$ & $4.5^{\mathrm{a}}$ & $2.8^{\mathrm{d}}$ & \\
\hline \multirow{5}{*}{$\begin{array}{l}\text { Total Fruit yield } \\
\text { (tonnes/ha) }\end{array}$} & PW & 3.0 & 4.5 & 3.0 & 4.0 & 1.5 & $3.2^{\mathrm{c}}$ \\
\hline & PM & 2.8 & 7.0 & 10.0 & 16.0 & 8.0 & $8.8^{\mathrm{a}}$ \\
\hline & $\mathrm{PG}$ & 3.0 & 4.0 & 6.0 & 9.5 & 6.0 & $5.7^{b}$ \\
\hline & NPK & 2.7 & 4.2 & 5.1 & 7.5 & 9.0 & $5.7^{b}$ \\
\hline & Mean & $2.9^{\mathrm{d}}$ & $4.9^{\mathrm{c}}$ & $6.0^{\mathrm{b}}$ & $9.3^{\mathrm{a}}$ & $6.1^{\mathrm{b}}$ & \\
\hline \multirow{5}{*}{$\begin{array}{l}\text { Average weight } \\
\text { of fruits }(\mathrm{kg})\end{array}$} & PW & 1.3 & 1.8 & 1.5 & 1.5 & 1.0 & $1.4^{\mathrm{c}}$ \\
\hline & PM & 1.1 & 2.0 & 2.5 & 2.8 & 3.7 & $2.4^{\mathrm{a}}$ \\
\hline & $\mathrm{PG}$ & 1.2 & 2.5 & 2.7 & 3.5 & 3.0 & $2.6^{\mathrm{a}}$ \\
\hline & NPK & 0.8 & 2.7 & 1.8 & 0 & 2.8 & $2.2^{\mathrm{a}}$ \\
\hline & Mean & $1.1^{\mathrm{c}}$ & $2.3^{\mathrm{ab}}$ & $2.1^{b}$ & $2.7^{\mathrm{a}}$ & $2.6^{\mathrm{a}}$ & \\
\hline
\end{tabular}

Means with the same superscript along the same row or column are not significantly different $(\mathrm{P}>0.05)$.

TABLE 6: ANOVA table of the effects of manure types, application rates and interactive effects on the total yield and yield characteristics of pineapple

\begin{tabular}{|l|l|l|l|l|}
\hline & \multicolumn{2}{|c|}{ Mean Squares } & Total fruit yield (t/ha) \\
\hline $\begin{array}{l}\text { Source of } \\
\text { Variation }\end{array}$ & df & $\begin{array}{l}\text { No. of blossomed } \\
\text { plants/plot by mid season }\end{array}$ & $\begin{array}{l}\text { Mean size (weight) of each } \\
\text { fruit (kg) }\end{array}$ & $13.85 \mathrm{~ns}$ \\
\hline Block & 2 & $3.20^{* *}$ & $0.23^{* *}$ & $50.72^{* *}$ \\
\hline Manure (A) & 3 & $4.55^{* *}$ & $3.93^{* *}$ & $34.25^{* *}$ \\
\hline Rate (B) & 4 & $8.85^{* *}$ & $1.24^{* *}$ & $14.32 \mathrm{~ns}$ \\
\hline A $*$ B & 12 & $1.55 \mathrm{~ns}$ & 0.04 & 6.16 \\
\hline Error & 38 & 0.62 & $\mathrm{~s}$ & \\
\hline
\end{tabular}

$* *$ significant at $\mathrm{P}<0.01 ; \mathrm{df}=$ degree of freedom; $\mathrm{ns}=$ not significant

\section{References}

[1]. O. N. Adeniyan, A. O. Ojo, O. A. Akinbode and J. A. Adediran, Comparative study of different organic manures and NPK fertilizer for improvement of soil chemical properties and dry matter yield of maize in two different soils, Journal of Soil Science and Environmental Management, 2 (1), $2011,9-13$.

[2]. C.R. Blatt, Comparison of several organic amendments with a chemical fertilizer for vegetable production, Scientia Horticulturae, 47, 1991, 177-191

[3]. A. Granstedt, The potential for Swedish farms to eliminate the use of artificial fertilizers, American Journal of Alternative Agriculture, 6 (3), 1992, 122 - 131.

[4]. O. B. Iren, J. F. Akpan, V. F. Ediene and E. E. Asanga, Influence of cassava peels and poultry manure-based compost on soil properties, growth and yield of waterleaf (Talinum triangulare Jacq) in an ultisol of south-eastern Nigeria, Journal of Soil Science and Environmental Management, 6 (7), 2015, 187-194. 
[5]. K. Hati, A. Swarup, A. Dwivedi, A. Misra and K. Bandyopadhyay, Changes in soil physical properties and organic carbon status at the topsoil horizon of a vertisol of central India after 28 years of continuous cropping, fertilization and manuring. Agriculture, Ecosystems \& Environment, 119, 2007, 127-134.

[6]. L. S. Ayeni and M. T. Adetunji, Integrated Application of Poultry Manure and Fertilizer on Soil Chemical Properties, Nutrient Uptake, Yield and growth components of maize, Nature and Science 8 (1), 2010, 60-67.

[7]. O. B. Iren, D. O. Asawalam, V. E. Osodeke and N. M. John, Effects of Animal Manures and Urea Fertilizer as Nitrogen Sources for Amaranthus Growth and Yield in a Rainforest Ultisol in Nigeria. World Journal of Applied Science and Technology(WOJAST), 3 (1), 2011, 73-78.

[8]. N. M. John, D. F. Uwah, O. B. Iren and J. F. Akpan, Changes in Maize (Zea mays L.) Performance and Nutrients Content with the

[9]. Application of Poultry Manure, Municipal Solid Waste and Ash Composts, Journal of Agricultural Science, Canadian Center of Science and Education, 5 (3), 2013, 270- 277. O. B. Iren, I. D. Uwah and V. E. Ekpenyong, Response of fluted pumpkin (Telfairia occidentalis, hook f.) to different levels of poultry manure application in an ultisol of southeastern Nigeria. Journal of Organic Agriculture and Environment, 3, 2015, 5 - 14.

[10]. A. Zsolnay and G.Gorlitz, Water extractable organic matter in arable soils, effects of drought and long term fertilization, Soil Biology \& Biochemistry, 26, 1994,1257-1261.

[11]. N. Blair, R. D. Faulkner, A. R. Till and K. E. Prince, The impact of plant residues with different breakdown rates on soil carbon and soil structure. In: Proc. $16^{\text {th }}$ ISTRO Conference, Brisbane, Australia, 2003, 175-181.

[12]. D. J. Udoh, O. B. Iren and J. E. Jonathan, Comparison of fish pond waste water with manures under garden egg (Solanum spp.) in Nigeria, Environment and Natural Resources Research, 6 (3), 2016, 58 - 64 (www.ccsenet.org.enrr).

[13]. FAO (Food and Agriculture Organization of the United Nation), The state of world fisheries and aquaculture, Opportunities and Challenges, FAO Rome, 2014).

[14]. E. J. Udo, I. A. Ogunwale, T. O. Ibia, A. O. Ano and I. E. Esu, Manual of Soil, Plant and Water Analysis (Sibon Book Limited, Lagos, 2009).

[15]. T. A.T. Wahua, Applied statistics for scientific studies (Afrika-Link Books,Ibadan, 1999).

[16]. D. Kendrick, Muskegon County Wastewater Management System Clean and Pure Water: The Essential Ingredient (Muskegon County Department of Public Works, 2005) 34-38.

[17]. L. Cooperband, Building Soil organic matter with organic amendment (Center for Integrated Agricultural Systems, Linden Drive, Madison, 2002).

[18]. L. Ferreras, E. Gomez, S. Toresani, I. Firpo and R. Rotondo, Effect of organic amendments on some physical, chemical and biological properties in horticultural soil, Bioresource Technology, 97, 2006, 635-640.

[19]. E. A. Aduayi, V. O. Chude, B. A. Adebusuya and S. O. Olayiwola, Fertilizer Use and Management Practice for Crops in Nigeria (Fertilizer Procurement and Distribution Division, Abuja, (2002).

[20]. S. C. Jarvis and A. D. Robson, The effect of nitrogen nutrition of plants on the development of acidity in Western Australian soils, I. Effects with subterranean clover grown under leaching conditions, Crop and Pasture Science, 34(4), 1983, $341-353$.

[21]. D. Sparks, Environmental Soil Chemistry (Academic Press, London, UK, 2003). 